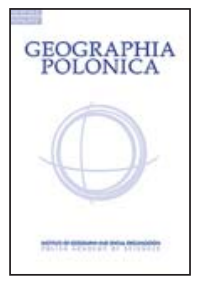

\title{
THE CONSERVATION OF TRAUMATIC RUINS: A SENSITIVE ISSUE TO IMPROVE URBAN RESILIENCE
}

\author{
Antoine Le Blanc ${ }^{1,2}$ \\ 1 Université du Littoral Côte d'Opale \\ F-59140 Dunkerque: France \\ ${ }^{2}$ TVES - Territoires Villes Environnement \& Société \\ Université de Lille \\ Lille: France \\ e-mail: Antoine.le-blanc@univ-littoral.fr
}

\begin{abstract}
Preserved urban ruins convey a social and political message, sometimes with great impact. Whereas stakeholders often tend to cancel the traces of disaster, the conservation of ruins has been the consequence of much disputed decisions. Such decisions can be explained by the will to use the conservation of ruins as a preventive tool. Indeed, the conservation of a disaster's traumatic marks can be a tool to perform urban resilience, since the urban system integrates the trauma, in an open purpose of risk mitigation. However, this instrument of risk management entails major urban planning issues. Many municipalities in various countries have decided to preserve ruins after tragic events. They set up specific restoration and management standards, various aesthetic and technical choices, access and presentation criteria, but they also indicate a political exploitation of the disaster.
\end{abstract}

\section{Key words}

risks $\cdot$ catastrophe $\cdot$ ruins $\cdot$ conservation $\cdot$ resilience

\section{Introduction}

Urban ruins are non functional buildings and as such are unwelcomed in most cities, where production and traffic density and efficiency prevail. But ruins do have functions in the city: they materialize urban memories, thus conveying a social and political message, sometimes with great impact. This paper deals with what I call "traumatic ruins", or "violent ruins", meaning ruins caused by catastrophic events such as earthquakes or bombings, as opposed to slowly degraded objects; according to Riegl's terminology, the latter are valued for their age, the former for their historicity. The analysis presented in this paper is half theoretical and half empirical: the data comes from personal empirical research and surveys regarding some cases (mostly Italian), but the focus has been 
widened to reach further theoretical meaning (Le Blanc, 2015, 2020).

In most cases of urban traumatic ruins, the pain and the will to rebuild have prompted stakeholders to cancel the traces of disaster, and the conservation of ruins was only due to much disputed decisions from the local authorities (Sauvageot, 1995). Such difficult decisions can be explained by the political benefit linked to the staging of catastrophes, but also by the will to use the conservation of ruins as a preventive tool. Indeed, traumatic ruins can be real urban scars reminiscent of a catastrophe to the local population. These memorabilia have sometimes been compared with "medals of merit on the community's chest" (Sauvageot, 1995) and can be considered a necessary step towards risk consciousness and the constitution of a risk culture. In other words, the conservation of a catastrophe's traumatic mark can be a tool to perform urban resilience (Reghezza-Zitt, Rufat, Djament-Tran, Le Blanc, \& Lhomme, 2012), since the urban system integrates the trauma instead of canceling it, in an open purpose of risk mitigation (Jackson, 2005). This specific process will be here called a proactive form of resilience (Vale \& Campanella, 2005).

But this instrument of risk management entails major urban planning issues. Should ruins be preserved as traces of history and a tool for remembrance and risk prevention, or should the trauma be erased in order to favor urban functionality? And how do we integrate a massive ruined element in an urban space?

Many municipalities in various countries have decided to preserve ruins after a tragic event. They set up specific restoration and management standards, various aesthetic and technical choices, access and presentation criteria. Two trends can thus be identified: on the one hand, immediate, bold conservation choices, which involve strongly symbolic monuments, mostly ruins of World War II (St Nicholas church in Hamburg, Germany - see Fig. 1, St Michael's Cathedral in Coventry, ruins of Oradour-sur-Glane in France, etc.); on the other hand, late choices, as in the case of Gemona (St-Mary) and Palermo (Holy Spirit) in Italy, or Christ Church Greyfriars in London. When the decision to preserve the ruins is made a few years after the disaster, the sense of pain is softened, and stakeholders can make more rational and aesthetic choices. In any case, it is argued that the conservation of ruins indicates a political exploitation of the catastrophe.

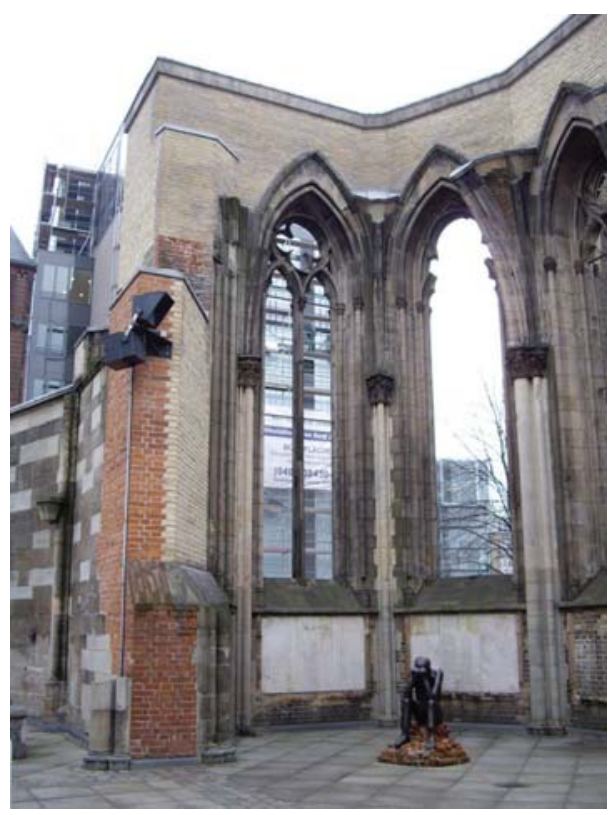

Figure 1. St Nicholas church in Hamburg, Germany, 2010

\section{The fate of the ruins}

The UNESCO defines a ruin as "a building that has lost so much of its original form and substance that its potential unity as a functional structure has also been lost" (Feilden \& Jokilehto, 1993). Ruins are not welcome in most cities today, where the efficiency of traffic and production seems to prevail. As a result, ruins are often destroyed, erased from the urban environment. However, they have very real urban functions, particularly in terms of identity; which explains that, in some cases, the actors of urban development 
have decided to maintain, preserve or even enhance ruins.

Historically, ruins were considered primarily as reservoirs of building material; it was not until the eighteenth century that their cultural value began to be perceived, thanks to social, political and economic changes that challenged traditional identities (Pinon, 1991). The following century, the question of the fate of the ruins was the subject of intense debate between the theories of Ruskin (restoration is the worst form of destruction of a monument) and Viollet-le-Duc (who advocated integral restoration), until consecutive currents (for instance Boito) proposed various forms of compromises, and eventually, in the middle of the twentieth century, rules concerning reconstruction and restoration were recognized at the international level. The reconstruction of a destroyed building is formally prohibited on the basis of scientific and aesthetic arguments at the 1931 Athens Conference, and reaffirmed in the Venice Charter in May 1964: "Any reconstruction work must be excluded a priori" (Article 15). These principles are taken up and specified in the theories of Brandi (1963), for whom it is neither normal nor respectful of History and Art, to rebuild a collapsed monument as it was, or to reconstitute a ruin. However, almost all restoration theories are still debated, probably in essence, as regards acts of a cultural and identity nature. As far as ruins are concerned, the debate, from the end of the twentieth century onwards, no longer focuses as much on the reconstruction of ruined buildings as on the use and museumization of ruins ${ }^{1}$. This debate could be reduced to a question, which is of particular interest to us in this chapter: should we let ruins die?

In reality, it is necessary to distinguish between several types of ruins, depending on their origin: this largely determines the message conveyed by the ruin, and therefore, by ricochet, the management choices

1 See for instance the international symposium Faut-il restaurer les ruines? (Should ruins be restored?) organized in Caen, France, in 1991. that will be made in relation to this spatial object. I take up a distinction, classic since Victor $\mathrm{Hugo}^{2}$, between two main types of ruins, which I will call 'slow' and 'violent' or 'traumatic's ruins. The former are the result of long historical processes and are linked to the cumulative action of time, people and various events. Violent ruins are the result of more punctual, more or less destructive events on different scales. They are the spatial materialization of a temporal discontinuity: traumatic ruins are the result of violent hazards, wars, earthquakes, but also accidental explosions, floods, fires (Sauvageot, 1995 : 59). Of course, in many cases, violent ruins gradually turn into slow ruins ${ }^{4}$.

In urban environments, violent ruins are scars, evoking the memory of a crisis, on different levels: the urban fabric is suddenly disrupted, traffic is modified, the functionality of space is interrupted, symbolic and spatial identity must integrate a more or less significant distortion. The inhabitants of the city, or transient individuals, face this urban disruption, which raises questions. The ruins, in an urban environment, can shock the observer, and carry messages whose meaning is difficult to manipulate. In the case of slow ruins, the major message that is transmitted is the awareness of the passing of time, of the historical action of mankind (both positive - the architecture of the past - and negative - the carelessness, the destruction), of the somehow

\footnotetext{
2 Victor Hugo differentiated ruins causes by violent destruction and ruins due to ageing.

3 A violent ruin is not necessarily traumatic; the hazard may be violent, whereas the trauma designates a consequence of the disaster. So the most accurate expression should be 'traumatic ruin', however I will sometimes use the expression 'violent ruin', to cover wider experiences of ruins. The historian Eric Fournier talks of 'brutal ruins' about the reconstruction of Paris after the 1870 war (Fournier, 2008).

4 Obviously, many traumatic ruins have become slow ruins, and there are many intermediate type of ruins (see for instance, Moshenska, 2015); however, this paper focuses on risk management choices entailed by the opposition between slow and traumatic ruins, and it has been considered more relevant for the analysis to start from this opposition and gradually take into account nuances for each case-study.
} 
normal evolution of the city. The message conveyed by a traumatic ruin is quite different: it recalls a violent and often painful event. This contrast creates two opposing attitudes towards the conservation of the ruin ${ }^{5}$.

As regards slow ruins, whose message is the passage of time, it is not logical to keep them in a state out of time, to remove them from the action of time. Two opposing options then appear more relevant: either the city's actors revive the ruin, by reusing it, by transforming it, which, historically, has been the fate of the vast majority of urban ruins (Federici, 2008); or they do not handle the ruin, the vegetation seeps in, the ground sinks in, the stones fall, which is considered by some theorists as the normal vocation of the ruin (Stanford, 2000). These options - transforming the ruin, or not managing it - can be analyzed as forms of resilience which I will call reactive (along with Dovers \& Handmer, 1992) and passive. On the other hand, for a traumatic ruin, the message is quite different. The issue is whether to consider or not the painful consequences of an event; whether to maintain or not the memory of the disaster, with the objective to prevent a potential future risk (war, earthquake, etc.). In this case, the logical action is to preserve the ruin as it is, to prevent it from gradually becoming a slow ruin, and to prevent the message from losing its initial strength. This could be called proactive resilience (Dovers \& Handmer, 1992). Certainly, the philosophical question is still asked: even violent ruins, can't we let them die? Should we force societies to remember? The actors of urban planning are faced with the paradox of trauma, which implies choosing between two terrible options: remembering the horror, or forgetting it ${ }^{6}$. The management of urban traumatic ruin raises this question: should we confront the inhabitants

5 I am focusing here on voluntary ruin management. Obviously, in many cases, ruins are not 'managed', and are simply left aside, abandoned to the destructive action of time. In these cases violent ruins become slow ruins.

6 This paradox shows particularly in the example of the French village of Oradour-sur-Glane (Stone, 2004). with their pain, or should we try to erase the wound? The answer to this question underwent a radical shift in the twentieth century: the Second World War, in particular, generated a surprisingly homogeneous desire throughout the world to preserve ruins in memory of the horror of war. The unprecedented scale of the disaster is not unrelated to the implementation of this proactive form of resilience; in other words, people have acknowledged the inadequacy of passive and reactive forms of resilience.

\section{A short history of the voluntary conservation of urban ruins}

A distinction must be made between interest in ruins and the idea of their voluntary conservation, particularly in the case of traumatic ruins. The birth, in the fifteenth century and in Europe, of a heritage cult focused mainly on ancient monuments, does not concern the other ruins, "widely considered as 'natural sites' that can be used according to purely technical criteria. A ruin is first of all a mass of masonry in which one can cut, on which one can build" (Pinon, 1991). According to Pierre Pinon, the cultural value of the ruins began to be perceived in the sixteenth century, but it was not until the end of the eighteenth century that this cultural value became more important than the utilitarian value. In a somewhat offbeat way, S. Lacroix dates the birth of this interest in the ruins of the 1740s, "when it became clear to the lucid man of the eighteenth century that he could no longer conceive the existence of universal benevolence" (Lacroix, 2007: 15). This interest would be the corollary of the "crisis of European consciousness". The extremely rapid social and spatial upheavals caused in particular by the industrial revolutions challenged traditional identities. The craze for ruins in any case reached a peak a little later, in the romantic exaltation of various kinds of remains, in letters and pictorial arts.

At the same time, theories about heritage conservation rapidly evolve from the cult 
of ancient monuments to other arts, countries and periods, to comprise more recent monuments, including ruins other than Greek and Roman ruins. It was then that the idea of the voluntary conservation of a recent, possibly traumatic, ruin developed from the middle of the nineteenth century onwards.

The context, in the middle and end of the nineteenth century, was also that of nascent urban planning in Europe and the United States, marked by theoretical excitement and intense debates, some of which focused on the place of ruins (one thinks of course of the opposition on this subject between Viollet-le-Duc and Ruskin). Still later, after the First World War, the city was compared to a living organism and became, in line with the success of psychoanalysis, the site of traumatic events, of which the ruins are traces, to be treated in a delicate way. At the end of the twentieth century, art historian Paolo Marconi stated that ruins, "with the problems that accompany them (biological infections, crumbling structures, loss of form), are certainly the most telling metaphors of the human skeleton and therefore constitute the ultimate representation of death, total disappearance and consequently permanent oblivion. It is precisely this omission that we wish to avoid when we consider that the monument is a work worthy of lasting for the message it contains, and that we want to transmit to our descendants" (P. Marconi in Sauvageot, 1995: 58). The invocation of anatomical and psychoanalytical metaphors (ruins in the city are physical or psychological traumas) thus becomes common, even if it must be qualified, as Françoise Choay explains in particular?

In Europe, before the nineteenth century, a few rare examples are precursors to the conservation of urban traumatic ruins for the purpose of memory and even risk

\footnotetext{
7 See especially Choay (2006). Françoise Choay refers to the 'palimpsest city' but warns that we should be very careful with this metaphor; she shows that cities do erase certain traces, contrary to the human memory. Hence the urban planner must not treat the city as a doctor treats a human body.
}

prevention: this is the case of a church in Lisbon (Convent of the Carms), preserved after the earthquake of 1755 . The case is exceptional in many respects.

A century later, in the United States, the ravages of the Civil War generated debates on the place to be given to ruins: are these traces of war violence useful, painful or ambiguous messages? For Americans, this is the first time their territory has been in ruins; the shock is considerable, and politically exploit$\mathrm{ed}^{8}$. The same debate, also intense, agitated Paris in the 1870s, about symbolic monuments with a highly political scope: should the burnt Tuileries palace be rebuilt? What about the destroyed City Hall? Should the ruins be preserved to denounce the massacres of the Commune forever? (Fournier, 2008).

Subsequently, one of the first attempts to implement this idea was made in Sicily in 1908: following a devastating earthquake, followed by an even more devastating tidal wave, the Messina Cathedral was destroyed. An intense debate then took place, and some of the theorists (including Giovannoni) proposed to keep the ruins as they were, so that the population would remember the disaster and develop a culture of risk prevention. In the end, the proposal was not accepted.

The same kind of debate, with the same final decision, took place for various monuments after World War I, for example for the Cathedral of Reims (André, 1986).

It was in fact following the immense destruction of World War II that the voluntary conservation of traumatic ruins had numerous applications in countries as different as Japan, Australia, Germany, the United Kingdom, Poland and France. From the Town Hall of Darwin in Australia to the village of Oradour-sur-Glane, the Cathedral of Coventry, the church of remembrance in Berlin, the church of Saint Nicholas in Hamburg, or the dome of Hiroshima, the reconstruction actors wanted to preserve spatial traces

\footnotetext{
8 The Los Angeles Getty Institute put up an exhibition on ruins and their treatment by artists after the Civil War.
} 
of the destruction, most often in memory of the horror, in tribute to the victims, and as an altar to peace, all goals which are in fact distinct and not without ambiguity.

The voluntary conservation of ruins due to violent events other than wars has not been as successful, if one can say so, or at least they came a little later. There are varied examples in very different places, a few of which are ancient: for example, in Macau, the Portuguese and then the Chinese have preserved the still standing façade of the Church of Saint Paul, destroyed by fire in the nineteenth century. In Avignon and Rome, the municipalities have preserved and made heritage of bridge arches destroyed by major floods in the Rhône and Tiber rivers. In Gemo$\mathrm{na}$, in the Italian region of Friuli, the municipality has voluntarily preserved the ruins of the Church of St Mary of the Angels, in the heart of the city destroyed by the 1976 earthquake, as a reminder of the disaster and a warning for the future. In Darwin, Australia, the City Hall was partially destroyed by bombing during World War II, but hurricanes completed the destruction in the 1970s, and the current ruins, preserved, bear witness to both disasters. Many other examples could be pointed out, in Hawai, Japan, or European countries, especially Eastern European countries with the urban legacies of the communist era.

\section{Conserving ruins to prevent future risk}

Among examples of the voluntary conservation of traumatic ruins, the majority reflect a desire to prevent future risk. The preserved traces of a catastrophic event awaken the observer's awareness of the risk: ruins raise questions, they bear witness to a disaster, and impose on the observer a reflection on the risk involved. The relationship to ruins, in this respect, has changed considerably in a few decades, as analysed by N. Gauthier and Y. Boiret: "The romantic tradition has accustomed us to a vision of the ruins where the dream prevails over reality. Hubert Robert's landscapes and the stories of 19th century traveller-archaeologists have reinforced this image. Today, the taste for history, the popularization of historical works, the passion for 'masterpieces in danger' have given rise to another approach to ruin. The visitor wants to understand what he sees, to identify the function of the monuments from which only foundations remain; in a word, to go beyond the sentimental impression to reach understanding" (Gauthier \& Boiret, 1991: 15). This more questioning attitude towards ruins is all the more true when it comes to violent ruins in urban areas, which contrast with the development of the rest of the city. The visitor stops in front of the ruin and wants to understand its history; he can be led to think about risk and disaster.

The American geographer J.B. Jackson highlights this challenge, this message of ruins, in a surprising but evocative way. After a brief development on the Berlin Remembrance Church - according to him "a huge ruin, without grace and picturesque, but which, for this very reason, acts as a powerful reminder of World War II, and whose message is not easily forgotten" (Jackson, 2005: 142) - he compares the ruins with the reminders of unpaid bills, "on yellow paper", by the telephone companies: "of good or bad grace, we will catch our cheque book to pay our dues and thus avoid further inconvenience (Jackson, 2005: 142).

Pain and trauma are not much studied in geography; theses topics are more studied in sociology, in studies of risk perception and disaster. However, the painful memory of a disaster is a determining factor in urban policies. The trace of an immediate and painful past is difficult to sustain: traumatized populations most often wish to erase the ruin, either by reconstructing the destroyed building identically, or by moving as quickly as possible to something else, by building something new, even if it means associating it with a memorial. Henri-Pierre Jeudy evokes this process in the following way: "Natural or industrial disasters do not cease to modify landscapes, they generate a constant metamorphosis of territories, and the ruins they leave behind seem to arouse horror rather 
than an aesthetic perception or a sovereign representation of the transmission of collective memories. It is said that disaster "must" not be forgotten, but the traces it caused are quickly erased to demonstrate the will to survive" (Jeudy, 1991: 49).

It is important here to highlight the fundamental difference between ruins as memorabilia, and a memorial, which is something built specifically for the purpose of memory; a distinction that evokes Françoise Choay's distinction between the monument and the historic monument (Choay, 1992). The buildings constructed on purpose do not ask quite the same questions as the ruins; their message may be very different. Monuments to the dead convey the memory of a disaster in a painful way, but through a sometimes ambiguous message. Jeudy (2001) expresses it as follows: "It is not only a question of fighting against oblivion, but of giving a posthumous meaning to the memory of the dead, a meaning that is always capable of being updated". In some cases, he explains, this meaning has the "conjurative vocation" of a "never again", as in the case of the Hiroshima memorial (Jeudy (2001:
92); so the message puts forward an ideal of peace. But it is not always the case. Very often, as the inscriptions show, these monuments favour a spirit of national pride over the desire to encourage peace. Many war memorials highlight hatred of the enemy, especially memorials from World War I. This feeling of national hatred or pride is exploited to dilute the feeling of pain. It should be noted, however, that the ambiguity of a memorial's message is not confined to monuments to the dead: it can be found in some debates concerning the reconstruction of a number of destroyed monuments and ruins. This was the case after World War I in Reims when, with regard to the possible preservation of the cathedral in ruins, the debate among intellectuals and artists saw arguments of this type flourish: "you have only one right, one duty, it is to preserve these ruins to our admiration, to our pain, so that our hatred will feed itself there, and renew itself from generation to generation ${ }^{9} . "$ However, in the Reims case, this position was not retained, which is a very substantial difference from war memorials (Fig. 2).

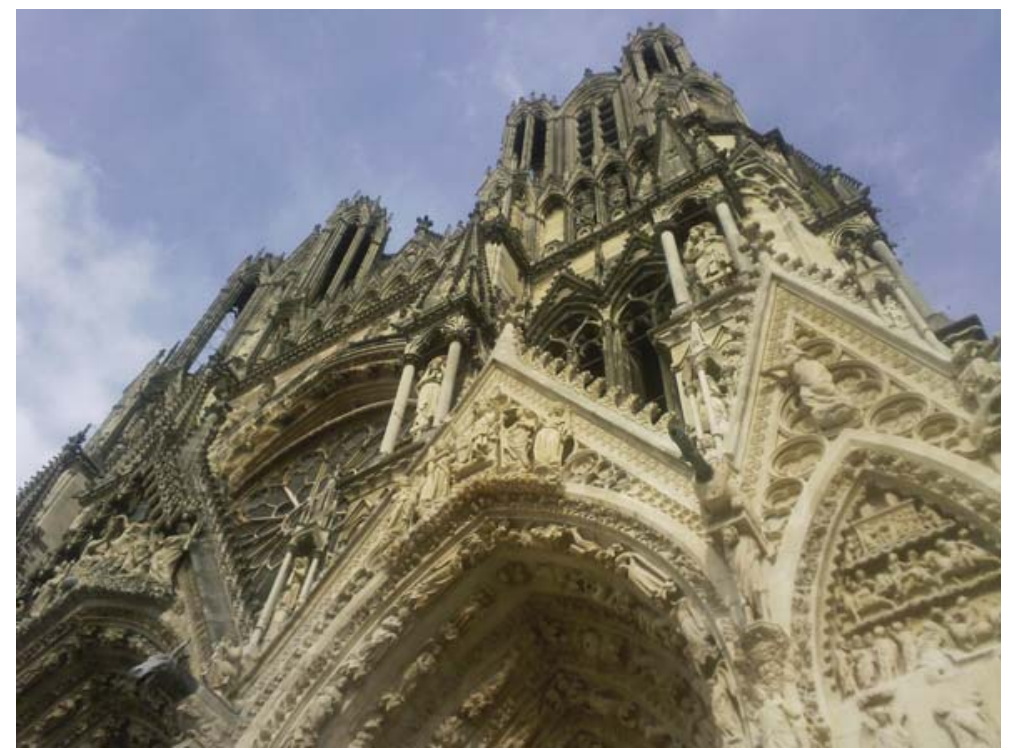

Figure 2. Reims Cathedral, 2009

9 Revue des Deux Mondes, quoted by Christian Dupavillon, in Sauvageot (1995: 75). 
The ambiguity of the message is also illustrated by a form that is somewhat intermediate between the ruin and the memorial, and quite widespread, as J. Sauvageot explains: "among these commemorations, the most common practice consists in the idea of leaving "on the spot", where the bomb exploded, or where the bombing took place, a tangible testimony of the cannon shots, such as the cannonballs embedded in the defensive wall of Pierrefonds or in the Aurelian Walls. These are substantially medals of Merit, pinned on the chest of the urban community, that the community accepts even when they are incongruous or from a bygone era" (Sauvageot, 1995). These "medals of merit" emphasize national pride rather than a culture of risk; but here again, there is a great difference between punctual traces limited in space, and the ruins of a destroyed and therefore non-functional building. The examples are significant: the impacts of bullets or shells in undestroyed walls do not make the construction lose its function, and on the contrary they evoke the idea of resistance, of victory in the face of an attack.

To deepen the difference between ruins and memorial, it may also be argued, albeit in a more cautious way, that the evocative and emotional power of ruins is greater than that of a memorial. The memorial, built after the disaster, is more easily accepted by the population, precisely because it is not a sharp wound, and the message is less powerful. Moreover, when the ruined building had architectural and artistic value, its remains acquire a particular value, to the point that Diderot could say: "You have to ruin a palace to make it an object of interest (Diderot, 1995: 348)." More poetically and more recently, Louis I. Kahn writes: "A building under construction is not yet in servitude. But it is so anxious to be in servitude, that no blade of grass can grow at his feet, so high is the spirit of existence he desires. When it is completed and in service, the building wants to speak out: "Look, I'll tell you how I was made". No one listens. Everyone is busy going from room to room. But, when the building is in ruins and freed from its servitude, the spirit emerges, saying how wonderful it is that a building has been built ${ }^{10 "}$. On another level, which illustrates the ambiguity of the message of the ruins, we can recall that under the Nazi regime, the architect Albert Speer advocated stone and brick to build the buildings of the Third Reich, because they age better than reinforced concrete. The buildings would then have been transformed into colossal remains testifying to the grandeur of the Reich (Ferranti, 2005).

The history of the Dresden Frauenkirche illustrates this dynamic of memory and risk prevention: it was kept in ruins to bear witness to the disaster of the bombing of the city at the end of World War II, and then rebuilt as it was before its destruction, when the benefit derived from the message became inferior to the cost of preserving the ruin (Le Blanc, 2015). Christian Dupavillon summarizes the issues highlighted by this example of the "Women's Church" as follows: "This church, which became a stone field following the bombings, is the city's monument against the war. Dresden was then in the East. Recently, since the fall of the Berlin Wall, the Conservatives have been questioning the condition of the stones that were deteriorating with the weather. Restoring them seemed more expensive than rebuilding the church as it was before the war. We are no longer in the 19 th century when ruins were in fashion. For simple economic reasons, a church, however remarkable it may be, will be rebuilt, a peace monument will be removed and the traces of war will be erased. This example is a fable: you can remove a monument against the war to rebuild a monument as it was before the war" (Sauvageot, 1995 : 74). Today, the church has been rebuilt and has regained its baroque splendour (Fig. 3); however, the reconstruction by anastylosis, respecting the theories of restoration of the second half of the twentieth century (see, among others, Brandi, 1963), led the rebuilders to distinguish between the original stones and the

10 L.I. Kahn, Silence et lumière, in Ferranti (2005). 


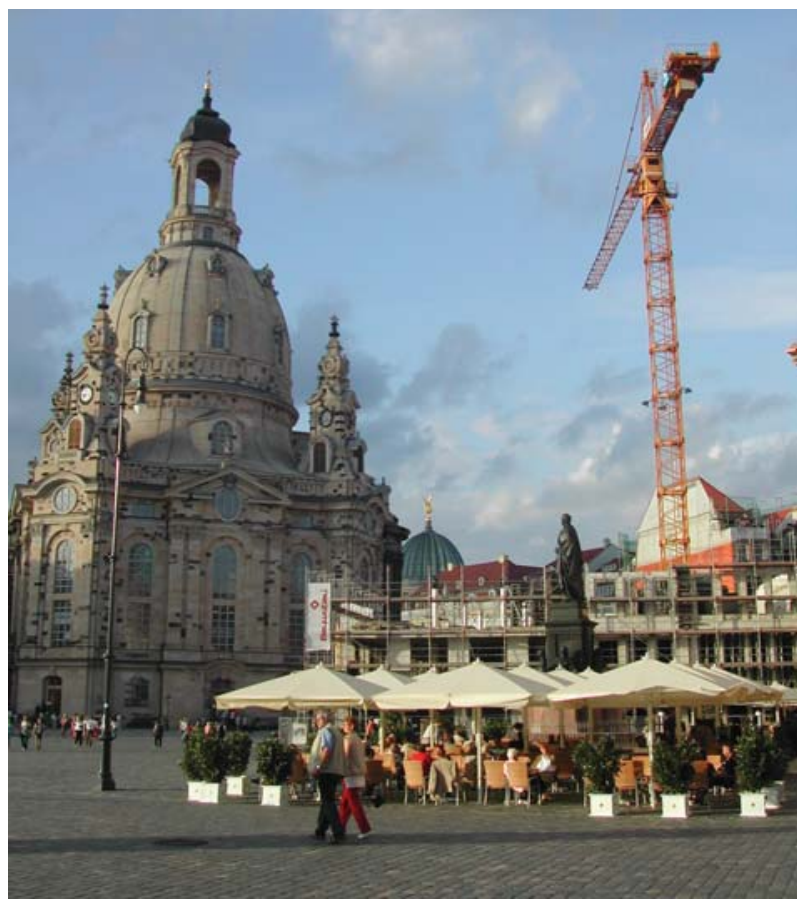

Figure 3. Dresden Frauenkirche, 2007

new ones, a clear contrast for inhabitants and tourists alike. The reconstructed church therefore raises questions through this contrast between the old and the new stones; the message of the disappeared ruin is not completely erased. Still, it is much less powerful today, because it is less visual and extremely attenuated by the aesthetic beauty and technical achievement of the monument. One can wonder whether the message desired by post World War II planners is still passed on, and whether this is a case of urban resilience, or if the memory of violent history is slowly being canceled.

As we can see, if ruins are "talkative", it is necessary to pay great attention to the ambiguity of their message; this is one of the difficulties in the management of what R. Robin calls the "fragile pasts" (Robin, 2001).

\section{The urban functions of the ruins}

The message of ruins in terms of risk prevention depends directly on the causes of destruction - in other words, whether or not it is possible to identify an enemy: the message will be substantially different, if the blame for the disaster lies with a person, a social group, or, say, fate. In some cases, those considered responsible for the disaster are alive and more or less easily identifiable (wars, technological accidents, terrorist attacks, fires, etc.). The consequences, reactions, and risk management methods are different if the hazard can be reduced to a fatality, a data considered natural, an earthquake, an eruption, a storm, a cyclone, among others. However, some recent examples - such as Hurricane Katrina in 2005 (Vale \& Campanella, 2005; Hernandez, 2008; Comfort, Boin, \& Demchak, 2010) or the L'Aquila earthquake in 2009 - show that populations affected by disasters presented as "natural" are increasingly blaming risk managers, especially elected officials and entrepreneurs, rather than the hazard itself. Anyhow, even when no immediately responsible person can be identified, the principle of ruin conservation 
remains the same: the process lies with remembering the disaster, and highlighting the risk and the resilience.

While the conservation of ruins has essential consequences in terms of risk culture, this statement must be qualified. The preservation of ruin indicates the memory of the event, and only indirectly the existence of a risk; it is only one element in the creation of a risk culture. Indeed, learning about a past disaster, and imagining that it could happen again, are two distinct mental processes, even if they have a deep and ambiguous connection. On the one hand, risk awareness implies a greater attention to the event than that resulting from a simple reminder of the disaster. On the other hand, risks and disasters involve a wide range of time horizons: not all risks are cyclical, and the reality of the disaster that has occurred is not systematically synonymous with future risk.

Securing and preserving ruins is not enough to ensure a proactive process of resilience. The ruin must also be presented, put into context, by means of educational information panels; this presentation of the ruin must be accompanied, as far as possible, by evidence that the risk is still present and real. For example, the developer may have educational or scientific tools reminding of the risk in or near the ruins. In reality, the voluntary conservation of a traumatic ruin in a city is a real urban planning issue.

Presenting urban ruins also means developing the city around the ruin: turning the remains into a kind of polarity. A violent ruin in an urban environment leaves a spatial, functional, psychological scar: redeveloping the space around the ruin, thanks to a proactive conservation policy, makes it possible to restore a function to the space in question, without erasing the trauma and its spatial trace. The urban landscape thus integrates trauma, but in order to sublimate it.

It is necessary to come back here on a frequent confusion: the preservation of a monument or ruin in a given state does not systematically lead to the much-discredited museumization of city centres, sometimes called mummification. City planners can preserve a ruin as it stands, and bring it to life, thanks to functional and landscaped developments. Moreover, unlike other monuments and slow ruins, violent ruins are not preserved primarily for aesthetic and artistic demonstration purposes. The museumization of city centres comes from the functional limitation of the enhanced elements, for which tourism seems to capture any other function and message of the building or site. Violent ruins can be exempt from this phenomenon, insofar as the immediate and most sensitive message is that of destruction, not the enhancement of artistic production and architectural techniques that generate admiration. In other words, the emotion caused by violent ruin is clearly distinct from the standardized reaction of admiration towards tourist sites or constructions. This is valid if the violent ruin is preserved as it is; if, on the contrary, it is left to abandonment and time, if it thus becomes a slow ruin, its message is attenuated, diluted in a feeling that gradually approaches the tourist admiration if the old monument was of value or the absence of interest for an abandoned urban space if the ruins are those of buildings less artistically interesting.

Moreover, the public is not the same as that of a museum or other tourist spaces: for the latter, the public makes an effort to get there; the entrance is often charged, and there is a specific public. In the case of an urban ruin developed as a promenade, for example, the park is freely and frequently accessible to poorer, more local and more diversified populations. This argument, of course, does not differentiate between violent ruins and slow ruins or other monuments, but rather between "museum-like" and lively developments.

So how can a ruined element be integrated into the urban space? The very term ruin is associated with negative connotations such as wasteland, decline, misery, destruction; it seems antinomic with the idea of a living city, a dynamic system. Some municipalities have preserved ruins and transformed this space into urban promenades or tourist 
attractions: they have given the ruins an original urban functionality. Through the reorganization of urban traffic around the ruins, they modified the urban structure according to an element that they considered as a potential rather than as a data from the past acting as a constraint. The range of new functions is rather varied, ranging from small urban parks for walking and meditation, such as in Gemona (Le Blanc, 2009) or London (Christchurch Greyfriars, St Duncan in the East, see Fig. 4) to the transformation of a site such as the Colosseum in Rome as a huge roundabout (Federici, 2008), through open-air concerts (Church of the Holy Spirit in Palermo, Royaumont Abbey), or the restoration of original functions (Church of Remembrance), not to mention of course the museum and educational function. If the ruin has been almost total, and the urban space is therefore open, relatively flat, the place can be appropriately chosen by municipalities as an emergency gathering area, in the event of an earthquake for example, after minimal development (consolidation of the ruins, access to a water point, traffic development, etc.). This variety of new functionalities and the creation of new urban dynamics could be measured, in specific cases, by different instruments: flow assessment (of inhabitants or tourists), questionnaires to the local population and visitors to the ruins (regarding the understanding of these ruins), measurement of visits to the municipality's website concerning the ruin, assessment of the inclusion of ruins in legal and urban planning documents.

Around monuments and ruins that have been deliberately preserved, there are often free spaces, transitions between "sacred" spaces and everyday urban space (Halbwachs, 1950)11: empty spaces in front of churches, squares in front of monuments, redesigned urban furniture around destroyed monuments... New urban spaces are created around these monuments and ruins: squares or gardens to open the view, to stage the majesty of the monumental space, but also to give the feeling of the sacred, the idea that we leave the everyday and banal space to enter a space that offers a message, which needs to be respected (Ricci, 2006: 20-21). In short, the layout of the urban space

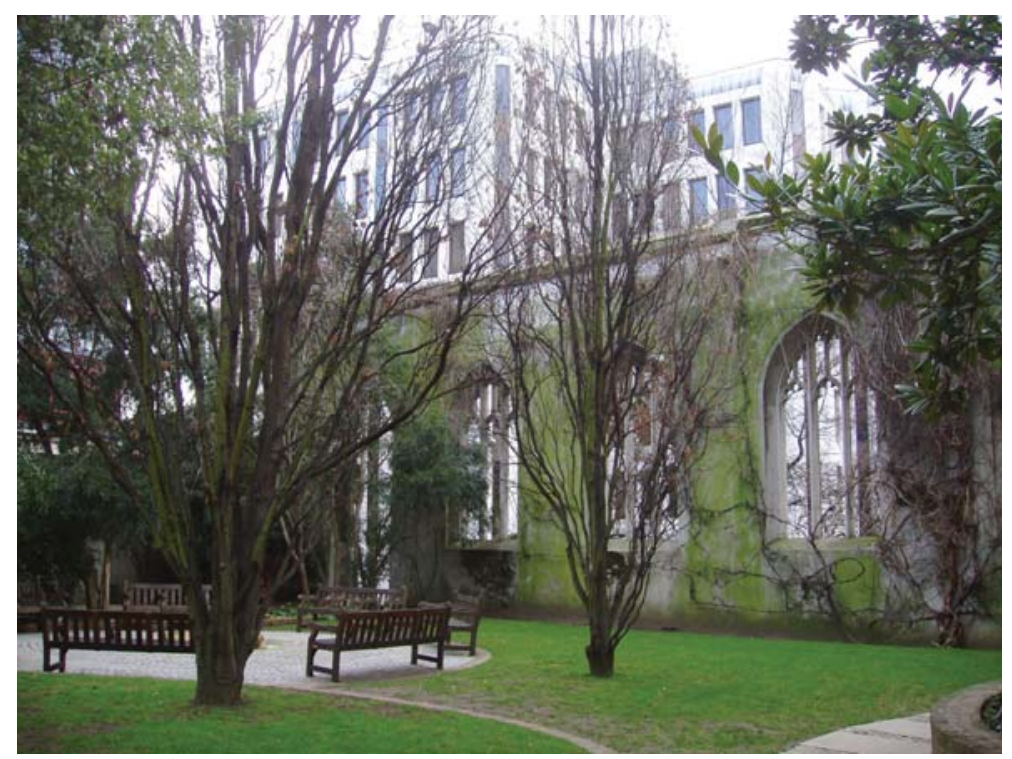

Figure 4. London Saint Duncan-in-the-East, 2012

11 Halbwachs showed how collective memory needed a specific space to be built on. 
around the monument is what creates a different perspective, what makes it monumental. The logic is no different when it comes to traumatic ruins. If the risk management message is to be strengthened, the ruins must also be separated from the daily urban fabric; the passer-by's gaze must be captured and directed. A ruin in a well-planned and neat urban space is more shocking and raises more questions than a ruin in the middle of urban wastelands. The spatial discontinuity then reflects the temporal discontinuity of the traumatic shock.

\section{Discussion}

It is difficult to make a general judgement on the success of projects for the conservation of traumatic urban ruins, as this depends on the achievements on a case-by-case basis and the nature of the message regarding disaster memory and risk awareness. However, specific surveys and urban developments tend to show that these choices are fruitful, when the project carries a carefully considered message and the implementation is integrated into an overall development of the surrounding urban space. In a survey
I conducted among the inhabitants of Gemona (Le Blanc, 2010), I asked whether, to their knowledge, there were still visible traces of the 1976 earthquake. Only 11\% answered in the negative, while $42 \%$ cited the Church of St Mary of the Angels. The preliminary survey is not statistically representative, but this figure, thirty years after the disaster, is quite significant. The municipality's bold urban planning choice seems to have contributed to the risk culture of the local population, and to accelerating a process of proactive resilience. The Church of Remembrance in Berlin, like the ruins of St. Nicholas in Hamburg, are now small urban polarities, both tourist targets and recognized symbols. On the other hand, the tourist heritage choices of the bridges in Rome and Avignon, or the discreet development of the ruins of the churches in Cologne (Fig. 5), do not seem to have brought back memories of disasters and therefore risk awareness.

Ruin management is ambiguous and delicate, particularly in the case of traumatic ruins in urban areas. The messages conveyed are powerful and extremely political in nature (Le Goic, 2009). Indeed, when urban planning actors manage to exploit a ruin to turn it into

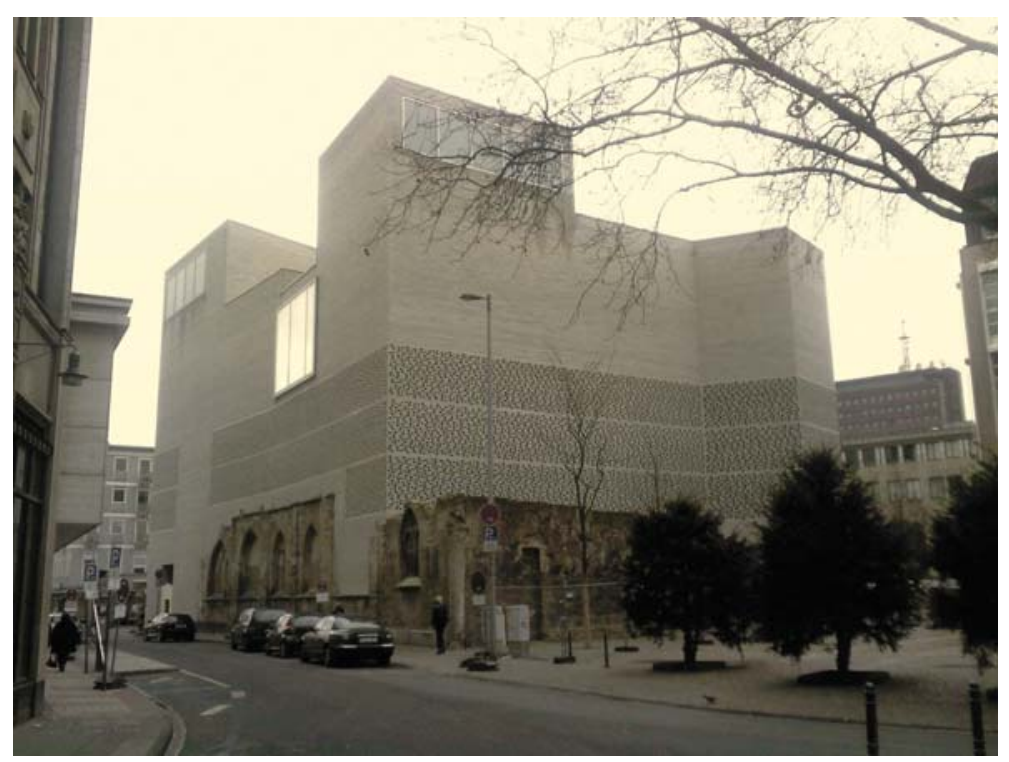

Figure 5. Cologne, Madonna in den Trummern, 2010 
a monumental spatial polarity, urban memory is reshaped, urban identity is redefined in depth, and a feeling of a political nature is generated in the population. Risk management, the designation of an enemy, the shaping of a message and an urban heritage identity, the orientation of the population's memory, are all factors in the politicization of a particularly delicate process. The traces of disasters can thus be read as "symbolic weapons" (Sauvageot, 1995: 60) used to "legitimize the attempts to revisit history" (Jeudy, 2001: 10). Or, as Gabriel Moshenska (2015: 89) puts it, "Ruins are disorderly, anarchic spaces, but ruins-as-memorials are serious places of business."

Paradoxically, these "political ruins" can also be interpreted as a sign of urban vitality, as Marc Augé says in Le temps en ruines
(2003). For him, ruins sometimes allow people to rediscover a meaning, a time, a world, that modern societies struggle to capture. The excessive heritage building, the refusal of risk, the standardization of certain lifestyles, would offer a spectacle too staged to be real and alive; but "the ruins, they still give sign of life" (Auge, 2003: 131) thanks to their evocative power, their enigmas, and their temporalities both long and fragile. Let us not forget that resilience means returning to a state of equilibrium, but also, and above all, that a local life is being re-established.

Editors' note:

Unless otherwise stated, the sources of tables and figures are the authors', on the basis of their own research.

\section{References}

Andre, M. (1986). Cathédrale de Reims. Monuments Historiques, 145, 113-114.

Auge, M. (2003). Le temps en ruines. Paris: Galilée.

Brandi, C. (1963). Teoria del Restauro, Rome: Editions Storia e Letteratura.

Choay, F. (1992). L'allégorie du patrimoine. Paris: Seuil.

Choay, F. (2006). Pour une anthropologie de l'espace. Paris: Seuil.

Comfort, L.K., Boin, A., Demchak, C. (2010). Designing resilience: Preparing for extreme events. Pittsburgh: University of Pittsburgh Press.

Diderot, D. (1995). Salon III: Ruines et paysages. Salon de 1767. Collection Savoir: Lettres. Paris: Hermann.

Dovers, S., Handmer, J.W. (1992). Uncertainty, sustainability and change. Global Environmental Change, 2(4), 262-276.

Faut-il restaurer les ruines? (1991). Actes des colloques de la Direction du Patrimoine, mémorial de Caen, Paris: Ministère de la Culture, Entretiens du Patrimoine.

Federici, F. (2008). Vincere il tabù dell'intoccabilità. // Giornale dell'Arte, 1 October 2008, p.48.

Feilden, B.M., Jokilehto, J. (1993). Management guidelines for world cultural heritage sites. Rome: ICCROM-UNESCO-ICOMOS.

Ferranti, F. (2005). L'Esprit des ruines. Paris: Hachette.

Fournier, E. (2008). Paris en ruines. Du Paris haussmannien au Paris communard. Paris, Imago.

Gauthier, M., Boiret, Y. (1991). Introduction au thème conservation-lisibilité. In Faut-il restaurer les ruines?

Halbwachs, M. (1950). La mémoire collective. Paris: PUF.

Hernandez, J. (2008). Le tourisme macabre à La Nouvelle-Orléans après Katrina: résilience et mémorialisation des espaces affectés par des catastrophes majeures. Norois, 208, 61-73.

https://doi.org/10.4000/norois.2208 
Jackson, J.B. (2005). De la nécessité des ruines et autres sujets. Paris: Editions du Linteau.

Jeudy, H.P. (2001). La machinerie patrimoniale. Paris: Sens \& Tonka.

Jeudy, H.P. (1991). Ruines en trompe-l'œil. In Faut-il restaurer les ruines?

Lacroix, S. (2007). Ce que nous disent les ruines: La fonction critique des ruines. Paris: L'Harmattan.

Le Blanc, A. (2009). La ville 30 ans après une catastrophe sismique: traces, identité, renouveau. L'exemple de Gémone (Italie). In C. Vallat, P. Philifert, A. Le Blanc (Eds.), Pérennité urbaine, ou la ville par-delà ses metamorphoses. Vol. 1 (pp. 161-171). Paris: Harmattan.

Le Blanc, A. (2010). La conservation des ruines traumatiques, un marqueur ambigu de l'histoire urbaine. L’Espace Géographique, 3, 253-266. https://doi.org/10.3917/eg.393.0253

Le Blanc, A. (2015). Resilience, memory and practices. In M. Reghezza-Zitt, S. Rufat (Eds.), Résilience imperative: Uncertainty, risks and disasters (187-199). London: ISTE Press.

Le Blanc, A. (2020). The conservation of traumatic ruins: A piece of memorabilia to perform urban resilience. In O'Reilly (Ed.), Places of memory and legacies in an age of insecurities and globalization (ch. 16), Springer Nature.

Le Goic, P. (2009). Traces et politiques de la trace : Brest, Lorient, Saint-Nazaire. In C. Vallat, P. Philifert, A. Le Blanc (Eds.), Pérennité urbaine, ou la ville par-delà ses metamorphoses. Vol. 1 (pp. 161-171). Paris: Harmattan.

Moshenska, G. (2015). Curated ruins and the endurance of conflict heritage. Conservation and Management of Archaelogical Sites, 17(1), 77-90. https://doi.org/10.1179/1350503315z.00000000095

Pinon, P. (1991). Construire sur les ruines. In Faut-il restaurer les ruines? (pp. 234-239).

Reghezza-Zitt, M., Rufat, S., Djament-Tran, G., Le Blanc, A., Lhomme, S. (2012).

What resilience is not: Uses and abuses, Cybergéo: European Journal of Geography, 621. https://doi.org/10.4000/cybergeo.25554

Ricci, A. (2006). Attorno alla nuda pietra. Archeologia e città tra identità e progetto. Rome: Donzelli.

Robin, R. (2001). Berlin, chantiers: Essai sur les passés fragiles, Paris: Stock.

Sauvageot, J. (Ed). (1995). Architecture monumentale et reconstruction: Actes du colloque. Ecole Régionale des Beaux-Arts (Rennes). Rennes: Presses universitaires de Rennes.

Stanford, C. (2000). On preserving our ruins. Journal of Architectural Conservation, 3, 28-43. https://doi.org/10.1080/13556207.2000.10785278

Stone, M. (2004). A memory in ruins?. Public Archaeology, 3, 131-144. https://doi.org/10.1179/pua.2004.3.3.131

Vale, J., Campanella, T.J. (Eds.). (2005). The resilient city. How modern cities recover from disaster. New York: Oxford University Press.

Vallat, C., Philifert, P., Le Blanc, A. (Eds.). (2009). Pérennité urbaine, ou la ville par-delà ses métamorphoses. Volume I: Traces. Paris: L'Harmattan. 